\title{
ASTAXANTHIN INCREASE AQP-5 MRNA LEVEL, SALIVARY FLOW RATE AND REDUCE F2-ISOPROSTANE LEVEL ON SUBMANDIBULAR GLAND OF WISTAR RATS WHICH IRRADIATED GAMMA RAYS
}

\author{
Haris Nasutianto ${ }^{1}$ \\ ${ }^{1}$ Departement of Dento-Maxillofacial Radiology Faculty of Dentistry, \\ Mahasaraswati Denpasar University \\ email: riskargi@gmail.com
}

\begin{abstract}
Aquaporin-5 (AQP5) is a water channel protein expressed on the apical membrane of serous acini in salivary gland. Previous study have shown that the level of mRNA AQP5 is decreased in irradiated rat that result in decreased salivary flow rate; however, the mechanism has not been reported. It's maybe due to presence of free radicals. The purpose of this study was to determine the effects of antioxidant on level of mRNA AQP5, salivary flow rate and F2 Isoprostane level (as biomarker of oxidative stress) on salivary gland of rats irradiated with $\gamma$ rays. All experiments were performed using Male Wistar Rat (Rattus Norvegicus, ages 3-4 month, weight 200 - 300 g) were randomly divided into 2 groups: the experimental group and the control group. Twenty two rats were irradiated with single dose $(10 \mathrm{~Gy})$ of $\mathrm{Co}^{60} \mathrm{Gamma}$ rays at ventral surface at their neck. Before irradiated, the experimental group (11 rats) were given $0.5 \mathrm{mg}$ Astaxanthin ${ }^{\circledR}$ for 4 days but not the control group (11 rats). Saliva secretion, saliva flow rate, and blood were collected after 24 hours. After that, submandibular glands were extirpated for analized mRNA AQP5 using Real Time-RT PCR. Level of F2 Isoprostane was analyzed by ELISA. Using independet t-test showed that mRNA AQP5 level and Flow rate saliva were significanly increased at experimental group ( $<0,05)$, plasma F2 Isoprostance level were significanly decreased at experimental group $(\mathrm{p}<0,05)$. Pearson correlation test demonstrate a strong correlation between levels of AQP5 mRNA with levels of F2isoprostane, mRNA AQP5 levels with salivary secretion, levels of mRNA AQP5 with salivary secretion rate, levels of F2isoprostane with the salivary secretion, and the levels of $\mathrm{F} 2$-isoprostane with salivary secretion rate. Using regression test showed a significant influence of level F2 Isoprostane toward the levels of mRNA AQP5 and the levels of mRNA AQP5 toward differences of salivary flow rate on submandibular gland. It can be conclude that antioxidant (Astaxanthin®) increased mRNA AQP5 levels, salivary flow rate and reduce levels of isoprostane F2 at Wistar rat irradiated with gammarays.
\end{abstract}

Keywords: mRNA Aquaporin 5, Salivary flow, F2 Isoprostant, Antioxidant, Gamma rays

\section{PENDAHULUAN}

Radiasi ionisasi merupakan terapi yang sering digunakan pada penderita keganasan di daerah kepala dan leher. Sifat radiasi ionisasi yang dapat menimbulkan efek biologis pada sel itulah yang dimanfaatkan untuk membunuh sel kanker. Meskipun memberi manfaat yang cukup besar, radiasi ionisasi juga menimbulkan efek negatif yang merugikan tubuh. Salah satu dampak negatif yang dilaporkan adalah xerostomia atau kekeringan rongga mulut.

Dosis total untuk terapi radiasi keganasan adalah 50 - 70 Gray (Gy). Dosis total 10 Gy sering digunakan dalam penelitian karena merupakan dosis radiasi yang tidak mengakibatkan kematian sel, sehingga fungsi sel masih dapat diamati. ${ }^{1}$

Salah satu efek samping terapi radiasi ionisasi keganasan di daerah kepala dan leher adalah Xerostomia. Xerostomia $($ xeros $=$ kering dan stoma $=$ mulut $)$ adalah perasaan subjektif mulut kering yang terjadi bila kecepatan sekresi saliva lebih rendah daripada berkurangnya saliva akibat penguapan dan penyerapan lewat mukosa rongga mulut. ${ }^{2}$ Xerostomia merupakan keluhan lebih dari $58 \%$ seluruh penderita terapi radiasi ionisasi keganasan di daerah kepala dan leher. ${ }^{3}$ Beberapa penelitian menunjukkan bahwa terjadi penurunan aliran saliva yang terjadi sekitar $50 \% .{ }^{4}$ Xerostomia ini akan mempengaruhi fungsi bicara, menelan, turunnya kesehatan gigi dan mulut serta mempengaruhi kualitas hidup. ${ }^{5}$ Hilangnya fungsi pengecapan adalah efek akut yang umum terjadi dan diperparah dengan adanya xerostomia. Hilangnya fungsi pengecapan ini sering diikuti dengan hilangnya nafsu makan, susah menelan, gangguan bicara dan turunnya berat badan. Proses penyembuhannya berjalan lambat dan seringkali tidak tuntas. ${ }^{1}$

Hilangnya fungsi saliva umumnya terjadi pada radiasi dosis sedang pada kelenjar parotis. Pada dosis 40 
- 60 Gy flow saliva sangat rendah sehingga kurang dari $20 \%$ pasien yang flow salivanya dapat diukur. Pada dosis kurang 30 Gy beberapa fungsi kembali normal setelah 6 sampai 12 bulan. Pada dosis di atas 50 Gy terjadi xerostomia yang ireversibel. ${ }^{1}$

Xerostomia terjadi akibat gangguan fungsi dari kelenjar saliva. Pada terapi radiasi ionisasi untuk keganasan di daerah kepala \& leher, kelenjar saliva akan terkena efek ionisasi sehingga mengalami kerusakan. ${ }^{6}$ Kelenjar saliva sangat sensitif pada radiasi, dan sel asinar serus pada kelenjar parotis lebih sensitif daripada sel mukus, sel asinar ini akan menyerap energi radiasi dan akan meningkatkan terlepasnya dan kerja dari radikal bebas. ${ }^{7}$ Diduga adanya logam transisi (transitional metals) misalnya $\mathrm{Fe}^{++}$dan $\mathrm{Cu}^{+}$dalam granula kelenjar serus akan meningkatkan pembentukan radikal bebas. Radikal bebas ini akan merusak integritas membran sel yang akhirnya akan menghambat sekresi saliva. ${ }^{8}$

Hingga saat ini penelitian untuk mengungkap mekanisme xerostomia akibat radiasi masih terus dilakukan. Salah satu cara untuk mengungkap mekanisme tersebut adalah melalui penelitian terhadap Aquaporin5(AQP5) dan peroksidasi lipid yang terbentuk pada kelenjar saliva akibat pemajanan radiasi ionisasi.

Aquaporin (AQP) adalah sekelompok protein saluran air (water channel protein) pada membran yang selektif terhadap air, dan bertanggung jawab terhadap trasport air melalui membran. AQP terdapat pada hewan, tumbuhan dan mikroorganisme, mempunyai fungsi sebagai saluran yang spesifik untuk air, dan atau zat terlarut yang netral seperti gliserol dan urea. Istilah aquaporin ini resmi digunakan pada tahun 1997 dan sampai saat ini dikenal 13 macam aquaporin, yaitu AQP0 sampai AQP12. ${ }^{9}$

AQP5 diketahui sebagai saluran air tipe eksokrin dengan ekpresi yang unik pada jaringan . Didapatkan mRNA AQP5 yang kuat pada beberapa kelenjar eksokrin seperti pada kelenjar saliva, mata, kelenjar lakrimal, paru dan trakhea. ${ }^{10}$ Beberapa penelitian menunjukkan bahwa AQP5 berkaitan dengan fungsi sekresi kelenjar saliva. ${ }^{11}$

AQP5 mempunyai peranan yang penting pada pergerakan air selama pembentukan saliva, air mata dan sekresi-sekresi lainnya ${ }^{12}$ sedangkan di kelenjar saliva, AQP5 merupakan aquaporin terbanyak yang diekpresikan di apikal membran sel asinar. ${ }^{13}$ Terdapat penurunan ekspresi mRNA dan protein AQP5 serta peningkatan kadar MDA (malondialdehida) setelah radiasi ionisasi. ${ }^{14}$

Penggunaan pemeriksaan kadar MDA untuk menentukan stres oksidatif mengandung beberapa kelemahan karena MDA bukanlah produk spesifik dari peroksidasi lipid demikian juga pemeriksaan dengan TBARS (Thiobarbituric acid-reacting substances) tidak spesifik untuk MDA. ${ }^{15}$

Saat ini biomarker terbaik untuk status stres oksidatif dan peroksidasi lipid in vivo adalah pemeriksaan kadar F2-Isoprostan. Walaupun F2-Isoprostan bukan produk utama dari peroksidasi lipid, metodologi saat ini dapat mendeteksi konsentrasinya secara in vivo. F2Isoprostan yang terdeteksi pada bentuk esterefikasinya dalam semua jaringan biologis normal dan dalam bentuk bebas dalam semua cairan biologis normal, mengindikasikan tingkat stres oksidatif. ${ }^{15}$

F2-Isoprostan adalah senyawa serupa prostaglandin yang terutama dihasilkan dari peroksidasi asam arakhidonat oleh radikal bebas. Proses ini tidak membutuhkan enzim cyclooxigenase (COX-1 dan COX2) untuk pembentukannya . Berdasarkan regio isomernya F2-Isoprostan dapat dibagi menjadi F2-, D2-, E2- dan J2isoprostan serta cyclopentenone-A2-isoprostan F2isoprostan paling reliabel untuk pemeriksaan stres oksidatif. $^{15}$

Pemeriksaan kelenjar saliva 8 minggu setelah iradiasi tidak ditemukan adanya perubahan mikroskopik pada kelenjar saliva dengan tidak ditemukannya kerusakan sel yang signifikan, vakuolasi sel asinar, atau pembesaran lumen asinar. ${ }^{6}$ Tidak terjadi kerusakan sel yang signifikan pada kelenjar saliva parotis tikus setelah 16 hari iradiasi $15 \mathrm{~Gy}$, namun terjadi penurunan flow saliva sampai $50 \%$. ${ }^{16}$ Diduga gangguan fungsi saliva oleh radiasi disebabkan oleh perubahan subseluler dan molekuler kelenjar saliva. ${ }^{6}$ Pemberian radiasi dengan dosis total 10 Gy merupakan dosis radiasi yang tidak mengakibatkan kematian sel, sehingga fungsi sel masih bisa diamati. Efek radiasi akut diamati 24 jam setelah iradiasi. ${ }^{1}$

Sampai saat ini belum ada informasi tentang peranan radikal bebas pada penurunan ekpresi mRNA AQP5 akibat radiasi ionisasi. Pada penelitian ini akan diteliti pengaruh radikal bebas pada penurunan ekpresi mRNA AQP5 dan pada radiasi ionisasi sinar $\gamma$ dosis tunggal $10 \mathrm{~Gy}$. Untuk mengetahui peranan radikal bebas maka sebelum radiasi diberikan terlebih dahulu antioksidan.

Antioksidan yang dipergunakan adalah Astaxanthin. Astaxanthin adalah antioksidan lipofilik alami yang termasuk golongan karotenoid dan berperan sebagai pencegah dan penetral radikal bebas. Astaxanthin merupakan antioksidan yang kuat, 10 lebih kuat dari beta karoten dan 550 kali lebih kuat dari vitamin $\mathrm{E}^{17}$ serta dapat berfungsi sebagai antioksidan yang larut air. ${ }^{18}$ Astaxanthin juga melindungi protein, DNA, asam lemak esensial dan komponen subseluler dari kerusakan oksidasi. ${ }^{18}$ Kadar F2Isoprostan juga akan diidentifikasi untuk mengetahui status stres oksidatif dan peristiwa peroksidasi lipid yang terjadi di membran sel serta menentukan adanya kerusakan oksidatif oleh radikal bebas dalam darah. Sebagai hewan coba digunakan tikus Rattus norvegicus galur Wistar

\section{BAHAN DAN METODE}

Penelitian ini menggunakan 22 ekor tikus Rattus norvegicus galur Wistar jantan berumur 3 sampai 4 bulan dengan berat badan 200 - 300 gram yang dipeliharan di 
Bagian Farmakologi Fakultas Kedokteran Universitas Udayana dengan ditempatkan pada kandang yang terpisah. Tikus secara random dibagi menjadi 2 kelompok, yaitu kelompok perlakuan dan kelompok kontrol. Kelompok perlakuan diberikan antioksidan Astaxanthin (Asthin Force ${ }^{\circledR}$ - Soho) melalui oral dengan sonde lambung dengan dosis $0,5 \mathrm{mg} /$ hari berbentuk larutan $1 \mathrm{ml}$ selama 4 hari berturut turut sedangkan kelompok kontrol tidak diberikan antioksidan. Dosis Astaxanthin yang diberikan mengacu pada perhitungan dari Tabel Konversi Perhitungan Dosis untuk Berbagai Jenis Hewan Uji ${ }^{19}$ dan dosis yang pernah digunakan untuk manusia.

Kemudian kedua kelompok diiradiasi dengan menggunakan Cobalt ${ }^{60}$ dengan dosis tunggal $10 \mathrm{~Gy}$ pada permukaan ventral leher tikus dengan waktu penyinaran selama 844 detik. Sebelum dilakukan iradiasi, tikus difiksasi dengan menggunakan jala-jala kawat yang khusus dibuat dengan diameter $7 \mathrm{~cm}$ dan panjang $15 \mathrm{~cm}$. Radiasi menggunakan Cobalt ${ }^{60}$ dari alat Tele Terapi Cobalt 60 FCC 8000 F (Zinhua Co) di Bagian Radioterapi RSUP Sanglah.

Setelah 24 jam, dilakukan pemeriksaan jumlah dan kecepatan sekresi saliva. Tikus dianestesi dengan chloroform. Produksi saliva distimulasi menggunakan pilocarpine $(80 \mathrm{mg} / \mathrm{kg})$ secara intraperitoneal (Cendo Carpine $\left.{ }^{\circledR}\right)$. Sekresi saliva diukur setelah 7 menit sesudah stimulasi dengan cara disedot dengan menggunakan spuit $1 \mathrm{ml}$ selama 5 menit dan dimasukkan kedalam tabung eppendorf. Jumlah saliva diukur dengan menggunakan pipet mikro. Pemeriksaan kecepatan aliran (flow) sekresi saliva dilakukan dengan cara jumlah sekresi saliva dibagi dengan lama pengumpulan saliva ( 5 menit).

Setelah pemeriksaan saliva, dilakukan pengambilan serum untuk memeriksa kadar F2 Isoprostan. Darah tikus diambil dari sinus orbitalis dengan menggunakan pipet kapiler hematokrit. Darah ditampung pada tabung eppendorf, kemudian disentrifus $3500 \mathrm{~g}$ selama 10 menit. Serum diambil dan disimpan pada lemari es dengan suhu $-20^{\circ} \mathrm{C}$. Pemeriksaan F2-Isoprostan menggunakan Direct 8-ISO-PGF $\alpha$ EIA Kit (Assaay Designs) dengan 96 well dan dibaca hasilnya dengan mesin ELISA. Kadar F2 Isoprostan diperiksa untuk mengetahui adanya radikal bebas dalam darah. Pemeriksaan dilakukan di Lab Virologi dan Patologi Veteriner Fakultas Kedokteran Hewan Universitas Udayana

Setelah itu tikus dikorbankan dengan cloroform dan diambil kelenjar submandibularisnya untuk pemeriksaan kadar mRNA AQP5 dengan menggunakan Real Time RT PCR. Tahapan yang dilakukan dalam pemeriksaan mRNA dengan menggunakan Real Time RT PCR adalah sebagai berikut : Persiapan/ Perlakuan Jaringan, Isolasi RNA total sampel, optimasi Primer secara konvensional dengan RNA sampel menggunakan metode One Step PCR, pembuatan cDNA dari RNA sampel, optimasi primer dengan mesin Real Time PCR menggunakan cDNA sampel, pembuatan Standar dari produk cDNA, running standar dengan cDNA sampel dengan alat Real Time PCR dan menghitung kadar mRNA sampel. Primer Aquaporin 5 (AQP 5) dipesan pada PT Diastika Biotekindo berupa Primer F (sense; 5'GCCACATCAATCCA GCCATT-3') dan Primer R (antisense; 5'-AAAGATCGGGCTGGGTTCAT-3') dengan panjang 383 bp. Sedangkan bahan yang digunakan adalah : High Pure RNA Tissue Kit (Roche), Trancriptor First Strand cDNA Synthesis Kit (Roche), SuperScipt@ III One Step RT PCR with Platinum ${ }^{\circledR}$ Taq (Invitrogen) dan FastStart SYBR Green Master (Roche). Pemeriksaan kadar mRNA AQP5 dengan menggunakan Real Time RTPCR dilakukan di Laboratorium Bio Sains Universitas Udayana dan Laboratorium Biomedik Fakultas Kedokteran Universitas Udayana.

Data dianalisis dengan menggunakan uji tindependent dan uji korelasi Pearson dan Regresi Linear

\section{HASIL DAN DISKUSI}

Hasil pengukuran kadar mRNA AQP5 pada kelompok tanpa Astaxanthin dan dengan Astaxanthin terlihat bahwa rerata kadar mRNA AQP5 pada tikus dengan pemberian Astaxanthin lebih tinggi dari pada yang tanpa Astaxanthin seperti yang terlihat pada tabel 1 .

Selanjutnya keduanya diuji dengan uji normalitas dengan menggunakan uji Shapiro-Wilk dapat disimpulkan bahwa kadar mRNA AQP5 pada kelompok tanpa dan dengan Astaxanthin berdistribusi normal ( $p>0,05)$.

Untuk mengetahui efek Astaxanthin terhadap kadar mRNA AQP5, maka perbedaan rerata antara kelompok kontrol dan kelompok perlakuan dianalisis dengan menggunakan t-independen.

Tabel 1. Uji t kadar mRNA AQP5 pada kelompok tanpa Astaxanthin dan dengan Astaxanthin

\begin{tabular}{|c|c|c|c|c|c|c|}
\hline \multirow[t]{2}{*}{ Kelompok } & \multirow[t]{2}{*}{$\mathrm{N}$} & \multirow[t]{2}{*}{$\begin{array}{l}\text { Rerata } \\
(\mu \mathrm{g} / \mathrm{ml})\end{array}$} & \multirow[t]{2}{*}{ SD } & \multicolumn{2}{|c|}{$\begin{array}{l}95 \% \\
\text { Confidence } \\
\text { Interval }\end{array}$} & \multirow[t]{2}{*}{$\mathrm{P}$} \\
\hline & & & & Lower & Upper & \\
\hline $\begin{array}{l}\text { Non } \\
\text { Astaxanthin }\end{array}$ & 11 & 2,18 & 2,70 & $-62,79$ & $-39,31$ & 0,000 \\
\hline Astaxanthin & 11 & 53,23 & 17,37 & & & \\
\hline
\end{tabular}

Dari hasil uji t dapat disimpulkan kenaikan kadar mRNA AQP5 pada kelompok perlakuan tersebut secara statistik bermakna $(\mathrm{p}<0,05)$.

Pemeriksaan sekresi dan kecepatan saliva tikus pada kelompok kontrol (tanpa astaxanthin) dan kelompok perlakuan (dengan astaxanthin) setelah kedua kelompok tersebut mendapat iradiasi sinar $\gamma$ dengan dosis tunggal 10 Gy. terlihat pada tabel 2: 
Tabel 2. Sekresi saliva dan kecepatan sekresi saliva

\begin{tabular}{|c|c|c|c|c|c|c|c|}
\hline \multirow{2}{*}{\multicolumn{2}{|c|}{ Kelompok }} & \multirow[t]{2}{*}{$\mathrm{N}$} & \multirow[t]{2}{*}{$\begin{array}{l}\text { Rerata } \\
(\mu 1)\end{array}$} & \multirow[t]{2}{*}{$\begin{array}{l}\text { SD } \\
(\mu 1)\end{array}$} & \multicolumn{2}{|c|}{$\begin{array}{l}95 \% \\
\text { Confidence } \\
\text { Interval }\end{array}$} & \multirow[t]{2}{*}{$\mathrm{P}$} \\
\hline & & & & & lower & upper & \\
\hline \multirow{3}{*}{$\begin{array}{l}\text { Sekresi } \\
\text { Saliva }\end{array}$} & Non & 11 & 316,09 & 8,78 & - & - & 0,000 \\
\hline & Astaxanthin & & & & 87,63 & 66,19 & \\
\hline & Astaxanthin & 11 & 393,00 & 14,61 & & & \\
\hline \multirow{3}{*}{$\begin{array}{l}\text { Kecepatan } \\
\text { Sekresi } \\
\text { Saliva } \\
\text { / menit }\end{array}$} & Non & 11 & 63,00 & 1,67 & \multirow{3}{*}{$\begin{array}{c}- \\
17,72\end{array}$} & \multirow{3}{*}{$\begin{array}{c}- \\
13,48\end{array}$} & \multirow[t]{3}{*}{0,000} \\
\hline & Astaxanthin & & & & & & \\
\hline & Astaxanthin & 11 & 78,60 & 2,92 & & & \\
\hline
\end{tabular}

Rerata sekresi saliva dan kecepatan sekresi saliva pada kelompok dengan Astaxanthin lebih tinggi daripada yang tanpa Astaxanthin. Sekresi dan kecepatan saliva pada kelompok tanpa Astaxanthin adalah 316,09 \pm $8,78 \mu \mathrm{l}$ dan $63,00 \pm 1,67 \mu \mathrm{l} /$ menit, sedangkan pada kelompok dengan Astaxanthin adalah 393,00 \pm 14,61 dan $78,60 \pm 2,92 \mu \mathrm{l} /$ menit. Untuk mengetahui apakah berbedaan rerarata sekresi dan kecepatan saliva antara kelompok kontrol dan perlakuan bermakna, dilakukan uji t-test independen. Dari hasil uji t di atas dapat disimpulkan bahwa sekresi dan laju sekresi saliva secara bermakna lebih tinggi pada tikus dengan pemberian Astaxanthin ( $\mathrm{p}<$ $0,05)$

Kadar F2-Isoprostan diperiksa dengan menggunakan mesin ELISA pada kelompok kontrol (tanpa diberikan Astaxanthin) dan kelompok perlakuan (diberikan Astaxanthin) setelah kedua kelompok diiradiasi sinar $\gamma$ dengan dosis tunggal 10 Gy. Tabel 3 memperlihatkan bahwa rerata kadar F2-Isoprostan pada kelompok perlakuan (diberikan Astaxanthin) lebih rendah dari pada yang tanpa Astaxanthin. Kadar F2-Isoprostan pada kelompok perlakuan $10,64 \pm 8,39 \mathrm{ng} / \mathrm{ml}$ sedangkan pada kelompok kontrol 46,76 $\pm 14,44 \mathrm{ng} / \mathrm{ml}$.

Tabel 3. Uji t kadar F2-Isoprostan pada kelompok tanpa Astaxanthin dan dengan Astaxanthin

\begin{tabular}{|c|c|c|c|c|c|c|}
\hline \multirow[t]{2}{*}{ Kelompok } & $\mathrm{N}$ & Rerata & SD & $\begin{array}{l}95 \% \\
\text { Interval }\end{array}$ & Confidence & \multirow[t]{2}{*}{ Sig } \\
\hline & & & & Lower & Upper & \\
\hline Non & 11 & 46,76 & 14,44 & 25,61 & 0,000 & 0,000 \\
\hline $\begin{array}{l}\text { Astaxanthin } \\
\text { Astaxanthin }\end{array}$ & 11 & 10,64 & 8,39 & & & \\
\hline
\end{tabular}

Dari hasil uji $\mathrm{t}$ dapat disimpulkan bahwa pemberian Astaxanthin akan menurunkan kadar F2isoprostan pada tikus yang diiradiasi sinar $\gamma$ sebesar $10 \mathrm{~Gy}$ secara bermakna $(\mathrm{p}<0,05)$.

\section{Hubungan antar variabel}

Dari hasil uji t, terdapat perbedaan yang bermakna antara kelompok kontrol (tanpa Astaxanthin) dengan kelompok perlakuan (dengan Astaxanthin) baik untuk kadar mRNA AQP5, sekresi dan kecepatan saliva serta kadar F2-Isoprostan pada tikus yang diiradiasi sinar $\gamma$ sebesar 10 Gy. Terjadi kenaikan kadar mRNA AQP5, sekresi dan kecepatan sekresi saliva serta penurunan kadar F2-Isoprostan yang bermakna pada pemberian Astaxanthin.

Untuk mengetahui apakah antar variabel mempunyai asosiasi/hubungan, dilakukan uji korelasi menggunakan analisis korelasi Pearson. Hasil Korelasi pearson tersaji pada tabel 4 .

Tabel 4. Korelasi Kadar mRNA AQP5, Sekresi dan kecepatan sekresi saliva serta kadar F2-Isoprostan

\begin{tabular}{clcc}
\hline Kelompok & & $\mathrm{R}$ & $\mathrm{Sig}$ \\
\hline mRNA AQP5 & F2-Isoprostan & $-0,80$ & 0,000 \\
& Sekr. Saliva & 0,84 & 0,000 \\
& Kec.Sekr Saliva & 0,83 & 0,000 \\
\hline F2-Isoprostan & Sekr. Saliva & $-0,85$ & 0,000 \\
& Kec. Sekr.Saliva & $-0,85$ & 0,000 \\
\hline Sekresi Saliva & Kec.Sekr.Saliva & 1,00 & 0,000 \\
\hline
\end{tabular}

Dari hasil uji analisis uji Pearson, didapatkan nilai koefisien korelasi antar semua variabel mendapatkan nilai $r>0,7$. Hasil tersebut menunjukkan bahwa terdapat hubungan yang kuat antara kadar mRNA AQP5 dengan Kadar F2-Isoprostan $(r=-0,80)$, antara kadar mRNA AQP5 dengan sekresi saliva $(r=0,84)$, antara kadar mRNA AQP5 dengan kecepatan sekresi saliva $(r=0,83)$, antara kadar F2-Isoprostan dengan sekresi saliva ( $r=$ 0,85), antara kadar F2-Isoprostan dengan kecepatan sekresi saliva $(r=-0,85)$ serta antara sekresi saliva dengan kecepatan sekresi saliva $(r=1)$ dan hubungan tersebut bermakna $(\mathrm{p}<0,05)$.

Untuk mengetahui apakah penurunan kadar F2Isoprostan mempunyai pengaruh terhadap kenaikan kadar mRNA AQP5 dan kenaikan kadar mRNA AQP5 berpengaruh terhadap kenaikan sekresi saliva maka dilakukan analisis regresi linier. Hasil uji regresi seperti pada tabel 5 .

Tabel 5. Hasil analisis regresi kadar F2-Isoprostan dengan kadar mRNA AQP5

\begin{tabular}{cccccc}
\hline $\begin{array}{c}\text { Uji } \\
\text { Regresi }\end{array}$ & $\begin{array}{c}\text { Koefisien } \\
\text { korelasi } \\
(\mathrm{r})\end{array}$ & $\begin{array}{c}\mathrm{R} \\
\text { Square }\end{array}$ & $\begin{array}{c}\text { Sig. } \\
\text { korelasi }\end{array}$ & $\begin{array}{c}\text { Koefisien } \\
\text { Regresi } \\
(\mathrm{b})\end{array}$ & $\begin{array}{c}\text { Sig. } \\
\text { Regresi }\end{array}$ \\
\hline $\begin{array}{c}\text { F2 } \\
\begin{array}{c}\text { Isoprostan- } \\
\text { mRNA }\end{array}\end{array}$ & 0,80 & 0,64 & 0,00 & $-1,06$ & 0,000 \\
AQP5 & & & & & \\
\hline $\begin{array}{c}\text { mRNA } \\
\text { AQP5 - } \\
\text { Sekresi }\end{array}$ & 0,841 & 0,707 & 0,00 & 1,199 & 0,000 \\
Saliva & & & & & \\
\hline
\end{tabular}

Kadar F2-Isoprostan dengan kadar mRNA AQP5 menunjukkan adanya korelasi yang kuat $(r=0,8)$ dengan koefisien determinasi $\left(\mathrm{R}^{2}\right)=0,64$ yang menunjukkan bahwa peran kadar F2-Isoprostan terhadap kadar mRNA AQP5 sebesar 64\%. Dapat disimpulkan bahwa kenaikan 
kadar mRNA AQP5 dipengaruhi oleh penurunan kadar F2-Isoprostan secara bermakna $(\mathrm{p}<0,05)$.

Hasil analisis regresi antara kadar mRNA AQP\% dengan sekresi saliva menghasilkan koefisien determinasi $\left(\mathrm{R}^{2}\right)=0,707$ yang bermakna $(\mathrm{p}<0,05)$, yang berarti bahwa peran kadar mRNA AQP5 terhadap sekresi saliva sebesar $70 \%$ sehingga dapat disimpulkan bahwa kenaikan sekresi saliva dipengaruhi oleh kenaikan kadar mRNA AQP5 secara bermakna.

Beberapa penelitian sebelumnya menunjukkan bahwa radiasi sinar $\gamma 10$ Gy menurunkan mRNA AQP5 pada hewan coba (Astuti, 2005) tanpa melihat peranan radikal bebas terhadap penurunan mRNA AQP5. Ada dua teori tentang radiasi ionisasi dalam memberikan pengaruh biologis pada sel, yaitu teori efek langsung dan teori efek tidak langsung. ${ }^{20,21}$ Teori efek langsung bila partikelpartikel ionisasi langsung berinteraksi dengan memindahkan enersi ke makromolekul biologi seperti DNA, RNA, protein atau ensim sehingga akan menimbulkan kerusakan. Teori efek tidak langsung berdasarkan pada anggapan bahwa radiasi menyebabkan kerusakan kimia pada sel oleh ionisasi pada air yang terdapat di dalam plasma yang menyebabkan terbentuknya radikal bebas. Radikal bebas ini akan mempengaruhi DNA, RNA sehingga menimbulkan kerusakan. Rusaknya RNA akan menyebabkan fungsi pembentukan protein terganggu. $^{22}$

Hasil Real time RT PCR untuk kadar mRNA AQP5 pada penelitian ini menunjukkan hasil yang berbeda antara kelompok yang mendapatkan Astaxanthin dibandingkan dengan kelompok tanpa Astaxanthin. Kadar mRNA AQP5 pada tikus yang diberikan Astaxanthin lebih tinggi daripada tikus yang tidak diberikan Astaxanthin. Dari hasil uji Independent t-Test perbedaan tersebut bermakna. Hal ini menunjukkan bahwa Astaxanthin sebagai antioksidan mempunyai pengaruh terhadap kenaikan kadar mRNA AQP5. Sebagai antioksidan, Astaxanthin berperan sebagai pencegah terbentuknya radikal bebas dan penetral radikal bebas. ${ }^{18}$ Hasil uji Korelasi - Regresi antara kadar F2-Isoprostan (yang menunjukkan adanya peningkatan stress oksidatif) dengan kadar mRNA AQP5 menunjukkan adanya hubungan dan pengaruh yang kuat dan bermakna. Kenaikan kadar mRNA AQP5 dipengaruhi oleh penurunan kadar F2Isoprostan secara bermakna.

Dengan demikian, dapat disimpulkan bahwa kerusakan mRNA AQP5 akibat radiasi adalah dikarenakan adanya radikal bebas yang terbentuk sebagai akibat ionisasi air yang terdapat dalam plasma yang membentuk radikal hidroksil. ${ }^{23}$ Radikal hidroksil apabila berikatan dengan asam lemak tak jenuh dapat menimbulkan suatu rangkaian reaksi yang disebut peroksidasi lipid. ${ }^{24}$ Peroksidasi asam arakhidonat oleh radikal bebas akan menghasilkan F2-isoprostan. F2-Isoprostan yang terdeteksi pada bentuk esterefikasinya dalam semua jaringan biologis normal dan dalam bentuk bebas dalam semua cairan biologis normal, mengindikasikan tingkat stres oksidatif. ${ }^{15}$ Berdasarkan penelitian ini, dengan pemberian antioksidan kerusakan akibat radikal bebas tersebut dapat dikurangi.

Dalam sintesa air liur, gen penyandi protein Aquaporin 5 (AQP5) ditranskripsi menjadi mRNA AQP5. mRNA AQP5 ini kemudian ditranslasi di dalam ribosom menjadi Aquaporin 5. Lebih rendahnya kadar mRNA AQP5 pada tikus yang tidak diberikan astaxanthin dibandingkan dengan yang diberikan astaxanthin menunjukkan bahwa rendahnya produksi air liur pasca iradiasi sinar gamma disebabkan oleh kerusakan tingkat gen. Hasil penelitian di ini sesuai dengan hipotesis penelitian bahwa pemberian Astaxanthin meningkatkan kadar mRNA AQP5 kelenjar submandibula pada tikus Rattus norvegicus galur Wistar yang diiradiasi sinar $\gamma$ dosis tunggal $10 \mathrm{~Gy}$.

Penurunan jumlah sekresi saliva pada tikus akibat iradiasi sesuai dengan penelitian beberapa peneliti yang lain. $^{14,16,25,26}$ Penyebab penurunan sekresi saliva diduga karena bermacam sebab. Diduga penurunan sekresi saliva tersebut karena terjadinya disfungsi dari kelenjar submandibularis akibat rusaknya eksositosis. ${ }^{25}$ Penelitian tentang efek radiasi fraksinasi pada berbagai dosis total pada pola matriks protein ektraseluler pada kelenjar submandibula tikus mendapatkan hasil bahwa iradiasi akan menyebabkan kerusakan matriks sel asinar sehingga sekresi saliva akan berkurang ${ }^{27}$ serta apoptosis pada sel asinar. $^{26,28}$ Namun dari penelitian yang lain tidak ditemukan adanya perubahan mikroskopik pada kelenjar saliva dengan tidak ditemukannya kerusakan sel yang signifikan, vakuolasi sel asinar, atau pembesaran lumen $\operatorname{asinar}^{6}$ serta tidak terjadi kerusakan sel yang signifikan pada kelenjar saliva parotis tikus walaupun terjadi penurunan flow saliva sampai $50 \% .{ }^{16}$ Diduga gangguan fungsi saliva oleh radiasi disebabkan oleh perubahan subseluler dan molekuler kelenjar saliva. ${ }^{6} \quad$ Terapi gen untuk memperbaiki fungsi kelenjar saliva tikus setelah iradiasi dengan menggunakan adenovirus yang membawa gen aquaporin ternyata dapat memperbaiki fungsi kelenjar saliva. $^{29}$

Hasil uji Korelasi - Regresi antara ekpresi mRNA AQP5 dengan jumlah sekresi saliva menunjukkan adanya hubungan dan pengaruh yang kuat dan bermakna. Demikian juga hasil uji korelasi -regresi antara kadar F2Isoprostan dengan sekresi saliva juga menunjukkan hubungan yang kuat dan bermakna. Dengan demikian penurunan sekresi saliva akibat radiasi lebih disebabkan berkurangnya kadar mRNA AQP5. Pemberian antioksidan juga meningkatkan sekresi dan kecepatan sekresi saliva.

Hasil penelitian menunjukkan bahwa rerata kadar F2-Isoprostan pada kelompok yang diberikan astaxanthin lebih rendah daripada kelompok tanpa astaxanthin. Hasil uji $\mathrm{t}$ menunjukkan bahwa perbedaan tersebut sangat bermakna dengan $\mathrm{P}<0,05$. Hasil uji regresi linier antara 
penurunan kadar F2-Isoprostan dengan kenaikan kadar mRNA AQP5 menunjukkan bahwa penurunan kadar F2Isoprostan mempengaruhi kenaikan kadar mRNA AQP5 secara bermakna $(\mathrm{P}, 0,05)$. Peran kadar F2-Isoprostan terhadap kadar mRNA AQP5 adalah sebesar $64 \%$.

Hasil penelitian di atas menunjukkan bahwa pemberian radiasi akan menyebabkan meningkatnya pembentukkan radikal bebas. Pembentukan radikal bebas ini akan menurunkan kadar mRNA AQP5. Dengan demikian, sebagaian besar efek negatif radiasi ionisasi diakibatkan karena terbentuknya radikal bebas. Hal ini sesuai dengan teori bahwa interaksi radiasi dan air adalah pembentukan pasangan ion $\mathrm{H}^{+}$dan $\mathrm{OH}^{-}$(ion hidrogen dan ion hidroksil) dan dua radikal bebas $\mathrm{H} \bullet$ dan $\mathrm{OH} \bullet$, karena $70 \%$ dari sistem biologi kita terdiri dari air, maka proses ionisasi banyak terjadi pada melekul-molekul air. ${ }^{21}$

Peran radikal bebas terhadap kadar mRNA AQP5 adalah sebesar 64\%. Dapat diduga bahwa efek negatif radiasi terhadap penurunan kadar mRNA AQP5 sebagian besar adalah diperantai oleh terjadinya radikal bebas (efek tidak langsung).

\section{SIMPULAN}

Pemberian Astaxanthin meningkatkan ekpresi mRNA AQP5 kelenjar submandibula, meningkatkan sekresi dan kecepatan sekresi saliva pada tikus Rattus norvegicus galur Wistar yang diiradiasi sinar $\gamma$ dosis tunggal 10 Gy. Pemberian Astaxanthin menurunkan kadar F2-Isoprostan. Berkurangnya kadar mRNA AQP5 akibat radiasi terutama dikarenakan peran dari radikal bebas.

\section{DAFTAR PUSTAKA}

1. Schreiber, G. J. 2007. Radiation therapy, general principles. Available from: http:// www.emedicine.com/topic247.htm. Last update: I Mei 2007. Tanggal akses 26 Juli 2007

2. Dawes, C. 2004. How much saliva is enough for avoidance of xerostomia? Caries Res; 38: 236-240

3. Rhodus, N. L. and Bereuter, J. 2000. Clinical evaluation of commercially available oral moisturizer in relieving signs and symptoms of xerostomia in postirradiation head and neck cancer patients an patients with Sjogren's syndrome. $J$ of Otolaryngology.29:28-34

4. Epstein, J. B., Emerton, S., Kolbinson, D. A., Le, N. D., Phillips, N., Stevenson-Morre, P.and Osoba, D. 1999. Quality of life and oral fuction following radiotheraphy for head and neck cancer. Head and Neck. 21(1):1-11

5. Sullivan, C. A., Haddad, R. I., Tishler, R. B., Mahadevan, A. and Krane, J. F. 2005. Chemoradiation-Induced Cell Loss in Human Submandibular Glands. Laryngoscope 115: 958-964

6. Vitolo, J. M., Cotrim, A. P., Sowers, A. L., Russo, A., Wellner, R. B., Pillemer, S. R., Mitchell, J. B., and Baum, B. J. 2004. The Stable Nitroxide Tempol
Facilitates Salivary Gland Protection during Head and Neck Irradiation in a Mouse Model. Clin Cancer Res 10: $1807-1812$

7. Spolarich, A. E. 2005. Medication use and xerostomia, treating drug-induced dry mouth. Dim Dent Hyg;3(7):22-24

8. O'Connel, A. C., Redma, R. S., Evans, R. L., Ambudkar, I. S. 1999. Radiation induced progressive decrease in fluid secretion in rat submandibular glands is related to decrease acinar volume and not impaired calcium signaling. Radiat Res. 151(2): 150158

9. Agre, P., King, L. S., Yasui, M., Guggino, W. B., Ottersen, O. P., Fushinori, Y., Engel, A., and Nielsen, S. 2002. Aquaporin water channels-from atomic structure to clinical medicine. Journal of Physiology. 542(1): 3-16

10. Raina, S., Preston, G. M., Guggino, W. B. and Agre, P. 1995. Molecular cloning and characterization of an aquaporin cDNA from salivary, lacrimal, and respiratory tissue. J Biol Chem.270:1908-1912

11. Murdiastuti, K., Miki, O., Yao, C., Parvin, M. N., Kosugi, C., Tanaka, Akamatsu, T., Kanomri, N. And Hosoi, K. 2002. Divergant expression and localization of AQP5, an exocrine type water channel in the submandibular gland of Sprague-Dawley rats.Arch Eur J Physiol. 445:405-412.

12. King, L. S. and Agre, P. 1996. Pathophysiology of the aquaporins water channels. Annu Rev Physiol. 58:619-648

13. Krane, C. M., Fortner, C. N., Hand, A. R., McGraw, D. W., Lorenz, J. N., Wert, S. E., Towne, J. E., Paul, R. J., Whitsett and Menon, A. G. 2001. Aquaporin 5deficient mouse lungs are hyperresponsive to cholinergic stimulation. PNAS. 98(24):14114-14119

14. Astuti, E. R. 2005. Efek iradiasi sinar Gamma terhadap ekspresi mRNA Aquaporin-5, ekspresi protein Aquaporin-5 dan kadar MDA kelenjar submandibularis Rattus Norvegicus galur Wistar jantan. Disertasi Program Pascasarjana Universitas Airlangga. Surabaya

15. Montuschi, P., Barnes, J. P., and Roberts II, L.J. 2004. Isoprostances: markers and mediators of oxidative stress. FASEB J. 18:1791-1800

16. Coppes, R. P., Roffel, A. F., Zeilstra, L. J., Vissink, A., Konings, A. W. 2000. Early radiation effects on muscarinic receptor-induced secretory responsivenesss of parotid gland in freely moving rat. Radiat Res Mar. 153(3):339-346

17. Maranan, J. T., 2001. Astaxanthin: this antioxidant shows promise in fighting macular degeneration an boosting immune fuction-supplement brief-cover story-brief article. Natural health. 
18. Guerin, M., Huntley, M. E. and Olaizola, M. 2002. Haematococcus astaxanthin: health and nutrional applications. Mera Pharmaceutical Inc.

19. Ngatidjan. 2006. Metode laboratorium dalam toksikologi. Bagian Farmakologi dan Toksikologi Fakultas Kedokteran UGM. Yogyakarta

20. White, S. C. and Pharoah, M. J. 2004. Oral radilogy principles and interpretation. $5^{\text {th }}$ ed. St.LouisLondon-Toronto. Mosby Inc. 25- 44

21. Gridley, D. S., Green, L. M., Nelson, G. A., Pecaut, M. J., and Slater, J. M. 2005. Therapheutic utilities of SOD mimetics cancer, radiotherapy and Sod mimetics. Available from: http://www.ncbi.nlm.nih.gov/books/bv.fcgi?rid=eurek ah.chapter. 32246. Tanggal akses 1 Agustus 2007.

22. Edwards, C., Statkiewicz-Sherer, M. A., and Ritenour, E. R. 1990. Perlindungan Radiasi bagi pasien dan dokter gigi. Alih bahasa: Lilan Yuwono. Widya Medika

23. Halliwell, B. and Gutteridge, J. M. C. 1999. Free radicals in biology and medicine. $3^{\text {rd }}$ ed. Oxford University Press. New York.USA

24. Suryohudoyo, P. 2000. Kapita Selekta Ilmu Kedokteran Molekuler. CV.Infomedika. Jakarta
25. Takagi, K., Yamaguchi, K., Sakurai, T., Hashimoto, K. And Terakawa, S. 2003. Secretion of saliva in Xirradiated rat submandibular glands. Radiat Res. 159(3): 351-360.

26. Paardekooper, G. M., Camelli, S., Zeilstra, L. J., Coppes, R. P. and Konings, A. W. 1998. Radiation induced apoptosis in relation to acute impairment of rat salivary gland fuction. Int J Radiat Biol. 73(6): 641-648

27. Friedrich, R. E., Bartel-Friedrich, S., Holzhausen, H. J. and Lautenschlager, C. 2002. The effect of external fractionated irradiation on distribution patern of extracellular matrix proteins in submandibular salivary glands of the rats. Craniomaxillofac Surg. 30(4):246-54

28. Boraks, G., Tampelini, F. S., Pereira, K. F. and Chopard, R. P. 2008. Effect of ionizing radiation on rat parotid gland. Braz Dent J. 19 (1):

29. Baum, B. J. and O'Connell. 1999. In vivo gene transfer to salivary glands. Crit Rev Oral Biol Med. 10(3): 276-283. 